\title{
Ecological risk assessment of glyphosate in surface water when it is used to control floating aquatic macrophytes
}

\author{
MARINA ANDRADA MARIA, SAMUEL R. CASTRO, LISÉTE C. LANGE, CLÁUDIA L.F. \\ SIÚVES \& AYLTON CARLOS SOARES
}

\begin{abstract}
The present work evaluated the ecological risk of glyphosate by its commercial formulation (Roundup Original ${ }^{\circledR}$ ) used to control floating aquatic macrophytes. Exposure analysis and ecological effects were performed from microcosm studies. The risk characterization was performed based on the calculation of the risk quotient. The commercial formulation of glyphosate had high toxicity when it was assessed separately. On the other hand, ecotoxicological evaluation of water samples from microcosms did not present toxicity to any tested organisms, however, glyphosate application is recommended exclusively to water bodies that have the surface completely covered by macrophytes.
\end{abstract}

Key words: herbicide, macrophytes, toxic effects, ecological risk assessment, aquatic toxicology.

\section{INTRODUCTION}

Ecological risk assessment of pesticides is a legal requirement in Brazil, recommended in the Decree $n$ o 4,074/2002 and in specific legislation of Brazilian Institute of Environment and Natural Renewable Resources - IBAMA (Ordinance no 84/1996). In this sense, some routines and procedures must be developed, data and information must be organized, evaluated, tested and all the uncertainties related to the pesticides behavior in the environment minimized, as well as their possible ecological effects in order to simplify, facilitate decision-making and to ensure a systematic implementation of legislation (IBAMA 2012).

The problem formulation on ecological risk assessments does not include a broad characterization of the environment (climate or soil) because it assumes that the products are directed to unspecific regions. However, relevant information of the product is required including potential uses, instructions for use, physicochemical properties and persistence, destination, transport and even information regarding effects in the environment by results of ecotoxicological tests (IBAMA 2012).

Risk assessment is carried out through a three steps process: problem formulation, analysis and characterization of the risk. (USEPA 2004). Analysis and characterization steps of ecological risk assessment must be described in quantitative terms (Peterson \& Hulting 2004). Risk quantification is performed in comparing the acute effect with the estimated environmental concentration that can be calculated by environmental models, mesocosms or field measurements (Inao et al. 2008). 
According to Peterson \& Hulting (2004) and Qu et al. (2011), ecological risk assessment is a study that should be evaluated by the risk quotient, which can be calculated for more than one substance, and being able to use the appropriate toxicity measure rather than only the acute toxicity.

Current models for calculation of herbicide availability in surface water consider data of partition coefficient, adsorption, solubility and half-life. These parameters estimate the environmental exposure from the soil runoff. In this case, it considers the effects related to the concentration reduction of the pesticides due to the adsorption in soil or sediment, the degradation before reaching the water, as well as the immediate deposition of the spray drift in the surface of the water bodies (Peterson \& Hulting 2004).

Brock (2013) reported that there are two main routes of exposure to pesticides, which may indicate risks to different communities of aquatic and terrestrial fauna, including plant species - food and water supplies. Evaluation of ecological effects estimates indirect risks from herbicide exposure and it should be analyzed for different groups of non-target, terrestrial and aquatic organisms, including birds, mammals, fish, aquatic invertebrates and plants (Peterson \& Hulting 2004).

Organisms are often exposed to complex mixtures of chemical contaminants, in a synergic way, causing combined effect in the environment. Toxic effects of the joint action of different molecules and additives should be considered and evaluated (Panizzi et al. 2016).

Authors such as Peterson and Hulting (2004) reported that is also important to evaluate the commercial formulation instead the active ingredient, as usual. According to such authors, this formulation may be more toxic.
According to Solomon et al. (2013), the risk assessment must always be expressed as a probability. The main challenge in risk characterization is the analysis of both exposure and effects, being desirable to consider differences of sensitivity among the species (Hayashi et al. 2016).

Water bodies are not usually treated as a focus area, once herbicides are commonly used in agriculture, and it is a new perspective. Therefore, the active ingredients from herbicides have their evaluated risk related to the primary contact with soil and then the surface of the water by leaching or drifting. Thus, it is necessary to evaluate the environmental risk inherent in the use of commercial formulation of herbicides for aquatic plant management.

In July 2015, the Brazilian Resolution no 467 from the National Council of the Environment (CONAMA 2015) was published and it establishes criteria for the use authorization of products or agents of physical, chemical or biological processes in controlling of organisms or contaminants in surface water bodies, and makes other provisions. Such Resolution indicates the need of the risk assessment of the intended intervention considering the peculiarities of the aquatic environment.

At this sense, the present work aims to evaluate the ecological risk of glyphosate in surface water in order to control floating aquatic macrophytes by its commercial formulation, Roundup Original ${ }^{\circledR}$. This study allows the identification of causes, risks sources, and favors the management plan to use this herbicide.

\section{MATERIALS AND METHODS}

The ecological risk assessment was performed considering the contamination of the surface water by the use of the commercial formulation 
of glyphosate, Roundup Original ${ }^{\circledR}$, for the management of floating aquatic macrophytes. It was considered the risk of the commercial formulation of glyphosate, its active ingredient and metabolite aminomethylphosphonic acid (AMPA) through the methodology proposed by IBAMA (2012) in four steps: (i) problem formulation, (ii) exposure analysis, (iii) ecological effects analysis and (iv) risk characterization.

\section{Problem formulation}

The problem formulation consists of a prior step of the product assessment aiming at predicting its adverse effects on the environment and exposure risks. In this step, the physicochemical characteristics of glyphosate were evaluated regarding its interaction with the environment. As a result, the hypothesis of environmental risk related to the use of the active ingredient and the conceptual model diagram were obtained.

Hypothesis of possible risks were supported by information such as persistence, destination and transport of the herbicide in the environment, as well as the establishment of the use pattern and recognition of non-target organisms.

Half-life of glyphosate was obtained in laboratory-scale experiments performed by the application of its commercial formulation in microcosms (as described below) and the quantification of the active ingredient solution in deionized water. Others parameters were also analyzed (Table I).

\section{Exposure analysis}

In this stage, the risk assessment was performed for both the glyphosate (active ingredient) and its metabolite AMPA. The estimation of the environmental concentration of these substances in water was carried out by simulating the reality. Thus, the commercial formulation of glyphosate was applied in microcosms for controlling aquatic macrophytes (target organism) and it enabled to evaluate and predict values of residual concentration of the active ingredient and its metabolite in water. These values were considered in the risk assessment study.

Table I. Physicochemical properties of Glyphosate.

\begin{tabular}{|c|c|c|}
\hline Properties & Values & Reference \\
\hline Molar mass & $169.1 \mathrm{~g} \cdot \mathrm{mol}^{-1}$ & Teófilo et al. 2008 apud Santos 2012 \\
\hline $\mathrm{pH}$ (in aqueous solution $1 \% \mathrm{~m} \cdot \mathrm{v}^{-1}$ ) a $25^{\circ} \mathrm{C}$ & 4.68 & FISPQ 2016 \\
\hline Relative density & $0.5 \mathrm{~g} \cdot \mathrm{cm}^{-3}$ & Teófilo et al. 2008 apud Santos 2012 \\
\hline Density at $20^{\circ} \mathrm{C}$ & $1.17 \mathrm{~g} \cdot \mathrm{cm}^{-3}$ & FISPQ 2016 \\
\hline Solubility in water $\left(\mathrm{S}_{\mathrm{w}}\right)$ & $12 \mathrm{~g} \cdot \mathrm{L}^{-1}\left(25^{\circ} \mathrm{C}\right)$ & Teófilo et al. 2008 apud Santos 2012 \\
\hline Acidity (pKa) & $<2.0,2.32,5.86,10.86$ & Teófilo et al. 2008 apud Santos 2012 \\
\hline Pressure value $(P)$ & $1.94 \times 10^{-7} \mathrm{mmHg}$ & FISPQ 2016 \\
\hline Partition coefficient $\mathrm{n}$-octanal-water $\left(\mathrm{K}_{\text {ow }}\right)$ & $\log$ Kow $=2.58$ & FISPQ 2016 \\
\hline Henry's Law $\left(K_{H}\right)$. & $<2.10^{-7} \mathrm{Pam}^{3} \cdot \mathrm{mol}^{-1}$ & Cabrera et al. 2008 \\
\hline Half-life (deionized water) & 21.6 & Author \\
\hline Half-life (microcosms) & 3.6 & Author \\
\hline
\end{tabular}


The microcosms were constructed in a standardized way and simulating an existing pond located in Belo Horizonte/MG, Brazil, with a hot and temperate climate, at the geographical

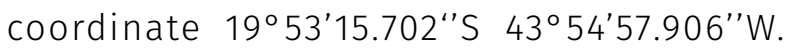
Average annual temperature is around $20.5^{\circ} \mathrm{C}$ and average annual rainfall about $1,430 \mathrm{~mm}$ (https:// pt.climate-data.org/location/2889/, accessed on April 11, 2017).

Each aquarium (microcosm) had $35 \mathrm{~L}$ of water and $4 \mathrm{~kg}$ of sediment in a 20 and $2 \mathrm{~cm}-$ columns, respectively, totaling $22 \mathrm{~cm}$ high. Moreover, it contained ten individuals of fish genus Poecilia, ten individuals of fish species Danio rerio, ten snails and eight individuals of aquatic macrophytes with average weight equal to $70 \mathrm{~g}$ (total of $560 \mathrm{~g}$ of Eichhornia crassipes (Mart.) Solms (1883) or $300 \mathrm{~g}$ of Salvinia sp). E. crassipes was chosen because it is the macrophyte with highest occurrence in Brazil. All the aquariums were laterally covered and kept in controlled environment: temperature of $23 \pm$ $2^{\circ} \mathrm{C}$ and luminosity of 3000 lux with photoperiod of $16 / 8$ hours light and dark.

Experiments were performed in triplicate for both aquatic macrophyte species ( $E$. crassipes and Salvinia sp.) in addition to the experimental controls, totaling six experiments. The microcosms had a unique application of the commercial formulation of glyphosate (Roundup

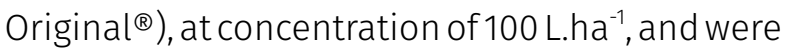
monitored during to 20 days. This concentration was established under laboratory tests that aimed at finding the lowest concentration with satisfactory effect on macrophytes in the tested period without evidence of regrowth. The doses commonly used in agriculture had no effect for macrophytes, being necessary a concentration higher than that indicated for terrestrial control.

The environmental concentrations of the active ingredient and the metabolite in water were obtained through the daily quantification of glyphosate and AMPA, respectively, by ion chromatography. Water samples have been collected from the six microcosms that were used as a simplification of the reality in order to evaluate and to predict the behavior and environmental destination of the product.

\section{Analysis of ecological effects}

Ecological effects analysis was carried out through ecotoxicological studies in order to evaluate the stressor-response relationship.

Acute and chronic tests were made by using microcrustaceans and bacteria. Working solutions were prepared at concentrations of $50{\mathrm{~mL} . \mathrm{L}^{-1}}$ for the commercial formulation (360g e.a. $\mathrm{L}^{-1}$ of glyphosate) and $50 \mathrm{mg} . \mathrm{L}^{-1}$ for both glyphosate and AMPA metabolite. Studies involving AMPA were conducted because it is the main glyphosate metabolite. In the case of the commercial formulation, it may have higher toxicity than the active ingredient.

Ecotoxicological assays were carried out with the same species and methodology in samples collected from the microcosms after 24 hours of the commercial formulation application, being evaluated the effects related to the environmental exposure to the product.

Survival, reproduction and growth are the main effects evaluated in ecotoxicological studies, which may be performed at community, micro or mesocosms levels. (IBAMA 2012).

It is important to select bioindicators species present in the exposure routes hypothetically plotted in the conceptual model diagram. Moreover, it enable the evaluation of effects of exposure to the stressor agent, considering the routes closest to the reality and non-target organisms.

However, in this study, only aquatic organisms were assessed, because of the environment susceptibility, using invertebrate 
organisms as bioindicators that present a higher sensitivity.

Acute ecotoxicity tests were carried out using standardized methodology and standard species of different trophic levels: Daphnia simillis (ABNT 2016a, NBR 12713) and Aliivibrio fischeri (ABNT 2012, NBR 15411-2). Chronic ecotoxicity was evaluated with Ceriodaphnia dubia species applying the methodology in accordance with ABNT 2016b, NBR 13373. All the related species have an ecological relevance in aquatic ecosystems and are widely used in standardized ecotoxicological tests.

The result of the acute test was presented by the median effective concentration $E C_{(1) 50}$ that was $48 \mathrm{~h}$ for $D$. similis and 5 to 30 minutes for A. fischeri. In the first case, immobility and/or mortality were the observed effects supported by a statistical analysis using PROBIT 1.5 program (West \& Dave 1994a). For A. fischeri bacteria, the decrease of the luminescence due to the exposure time was the considered criteria, evaluated by a correlation factor calculated using the Omni software and supported by equipment such as luminometer of the Microtox ${ }^{\circledR}$ M500 Analyzer System and lyophilized Biolux ${ }^{\circledR}$ biomass NRRL-B-11177.

The result of the chronic test was given by $E C N O_{(I)}$ (initial effect concentration not observed), obtained through statistical analysis using the TOXTAT 3.3 program (West \& Dave 1994b).

\section{Risk characterization}

The risk characterization stage comprises the effective integration of exposure to the product with ecological effects. In a deterministic approach, the most restrictive result is considered and this integration means the calculation of the risk quotient as the ratio between the estimated exposure and the considered effect by the ecotoxicological study.
The results can be discussed on an acute or chronic basis.

Risk characterization procedure was the same for the active ingredient, metabolite and commercial formulation of glyphosate. For this last one, the calculation was not done aiming at assessing the specific risk, but understanding the effect in order to find explanations in ecosystem studies related to the risk of the active ingredient.

It needs to be highlighted that such risk assessments are related to the use of the active ingredient of glyphosate in surface water bodies for controlling aquatic macrophytes. The rate and the use pattern must be considered for each specific product (IBAMA 2012).

$$
R Q=E C / E C N O \text { ou } E C_{(I) 50}
$$

Where:

$\mathrm{RQ}=$ Risk quotient

$\mathrm{EC}=$ Environmental concentration ( $\mathrm{mg} . \mathrm{L}^{-1}$ )

$\mathrm{ECNO}=$ Effect concentration not observed in chronic toxicity test

$\mathrm{EC}(\mathrm{I})_{50}=$ Median effective initial concentration of acute toxicity tests

According to Hayashi et al. (2016), the risk quotient $(R Q)$ is calculated by the ratio between the maximum environmental concentration and the concentration related to $50 \%$ of inhibition $\left(I C_{50}\right)$. A quotient value higher than 1.0 means that the maximum environmental concentration exceeds the $\mathrm{IC}_{50}$, and then the studied site has a high risk involved.

The RQ obtained must be compared to the risk assumption and levels of concern adopted in according to USEPA (2004). The acute risk assumption (LOC) for aquatic organisms is equal to 0.5 and the chronic risk for all animals is equal to 1.0. In this study, the RQ was compared using the LOC value of 1.0 for both the acute and chronic analyzes. The LOC value equal to 
1.0 means that the maximum environmental concentration is the same as that presents an ecotoxicological effect with imminent risk. In this way, aquatic organisms are subject to risks when $\mathrm{RQ}>1.0$.

The references of maximum tolerable value for the active ingredient of glyphosate that can be found in the state and federal environmental legislations from Brazil are lower than the estimated concentration of exposure. This observation is due to the fact that legislations are based on the risk of indirect contamination of the water bodies and are mainly related to the use of herbicides in agricultural activities (Ministério da Saúde 2011, Ordinance no 2,914/2011 and CONAMA 2005, Resolution no 357/2005, CONAMA 2011, Resolution no 430/2011 and COPAM 2008, 01/2008). For this reason, these concentrations were not considered as the maximum concentration of glyphosate in water.

Finally, results of ecotoxicological studies, acute or chronic basis, must be assessed separately because of their different conduction times and sensitivity levels.

In this scenario, it would be desirable to assess the risks to birds that can feed from the affected macrophytes and non-target plants, especially those of margin, which may be affected by drift during the application process, but these evaluations were not performed due to the absence of exposure data and effect for these groups.

\section{RESULTS AND DISCUSSION}

Glyphosate is a phosphonate $\left(\mathrm{C}_{3} \mathrm{H}_{8} \mathrm{NO}_{5} \mathrm{P}\right)$, called $\mathrm{N}$-(phosphonomethyl) glycine by IUPAC. It is an herbicide for agricultural use with high efficiency in weeds control acting in a non-selective and systemic manner. According to the label of its commercial formulation, glyphosate is classified as a kind of glycine with substituted chemical group included in the toxicological class III, being considered moderately toxic.

Chemical Product Safety Information File Card (FISPQ) of the Roundup Original ${ }^{\circledR}$ classifies the mixture as extremely toxic and with Environmental Hazard Potential III, being a dangerous product to the environment. Glyphosate has routes of exposure and absorption by respiration, digestion, dermis and mucosa.

The main physicochemical properties determine the herbicides behavior in the environment and are directly related to their persistence and/or degradation. In this sense, it is important to know and understand how each property and characteristic influences the herbicides behavior. The main glyphosate properties are listed in Table I.

The solubility $\left(\mathrm{S}_{w}\right.$ ) of glyphosate is $12 \mathrm{~g} \cdot \mathrm{L}^{-1}$ in water at $25^{\circ} \mathrm{C}$. This is the maximum amount of glyphosate that can be solubilized in water at such temperature, above which two distinct phases will coexist.

Glyphosate has low volatility and it can be ratified by the value of vapor pressure $(P)$ equal to $1.94 \times 10^{-7} \mathrm{mmHg}$, which indicates a tendency of volatilization of the compound in its pure normal state. According to Beltrão (2010), the vapor pressure can be classified in: $P$ $>10^{-2} \mathrm{mmHg}$ are considered very volatile at room temperature; $10^{-4}<\mathrm{P}<10^{-3}$, moderately volatile; $10^{-7} \leq \mathrm{P} \leq 10^{-5}$, low volatile; and $\mathrm{P}<10^{-8}$, non-volatile.

The partition coefficient n-octanol-water $\left(\mathrm{K}_{\text {ow }}\right)$ is a parameter that is related to the herbicides behavior and destination in the environment. Values of $\log \mathrm{K}_{\mathrm{ow}}>4.0$ indicate an accumulation of the herbicide in the organic fraction of sediments, on the other hand, $\log \mathrm{K}_{\text {ow }}$ values $<1.0$ indicate more solubility in water with low adsorption in sediments. Glyphosate $\mathrm{K}_{\text {ow }}$ has 
a mean value equal to 2.58 , which represents its good solubility in water; however, it often tends to be adsorbed by sediments.

The ionization constant ( $\mathrm{pKa}$ ) indicates the $\mathrm{pH}$ values that promote different states of ionization. The ionization of glyphosate occurs in a wide $\mathrm{pH}$ range (2 to 10), culminating in rapid changes.

Henry's law constant refers to the partition coefficient of the herbicide in air-liquid or vaporliquid. The higher is the $\mathrm{K}_{H}$ value, the higher is the volatilization potential of the molecule, however, $\mathrm{K}_{H}$ value decreases with increasing herbicide solubility in the liquid phase (Prata 2002). Glyphosate has low $K_{H}$ values, which reflects its characteristics such as low volatilization capability and the consequent high solubility in liquid. Generally, the soluble compounds have low sorption coefficients, except for those, even soluble, that have high affinity for adsorption in soil such as glyphosate (Beltrão 2010).

The half-life is an indicative of the molecule persistence and it is the time required for the concentration of a substance to halve its original value in a particular environmental medium. Glyphosate is rapidly degraded in natural environments and can remain stable for longer periods in environments free of microorganisms and ionic species.

It is important to highlight that the commercial formulation of herbicides is a mixture of "several ingredients", not informed in respect to the trade secret, which makes it difficult to assess their behavior, physicochemical characteristics or toxicity.

According to Carvalho (2013), commercial formulations have adjuvants that are substances that aimed at maintaining stability in order to facilitate application, increase efficiency and decrease risks. These substances can influence the herbicide behavior in several ways, for instance, dispersants (avoiding agglomeration of particles), emulsifiers (making compatible polar and nonpolar fractions), thickeners (increasing viscosity), solvents (turning the active ingredient soluble), wetting agents (putting the product in contact with water) and buffering (keeping the $\mathrm{pH}$ value within a desired range).

Risks can be minimized by the direct application of the herbicide in the target organism avoiding excesses that can reach water bodies, where it becomes soluble and more available to the aquatic biota even if it is mainly adsorbed on suspended particles and sediments.

Figure 1 has the conceptual model diagram with the environmental risk related to the use of the commercial formulation of glyphosate in controlling floating aquatic macrophytes.

It is relevant to note that much of the risk is related to the application and the inherent risk of direct contact with non-target organisms. In this way, the risk is associated not only to aquatic organisms but also to terrestrial organisms, including riparian vegetation (ciliary forest), birds and insects. The possible effects are the same for all exposed organisms, including different symptoms range from death to reduction in reproductive capacity.

A volume of $1.8 \mathrm{~mL}$ of the commercial formulation of glyphosate (648 mg equivalents) were applied by spraying in the microcosms, resulting in a final concentration about $18.5 \mathrm{mg}$ e.a. $\mathrm{L}^{-1}$. However, part of this concentration remains in the macrophytes leaves during the application process that could cause lower concentrations in the water.

Concentration data of glyphosate were taken 24 hours after application, when an initial decrease in the measures was identified. Table II has the descriptive statistics for glyphosate and AMPA data obtained from the microcosm experiments. The mean value recorded for glyphosate concentration in the six microcosms 


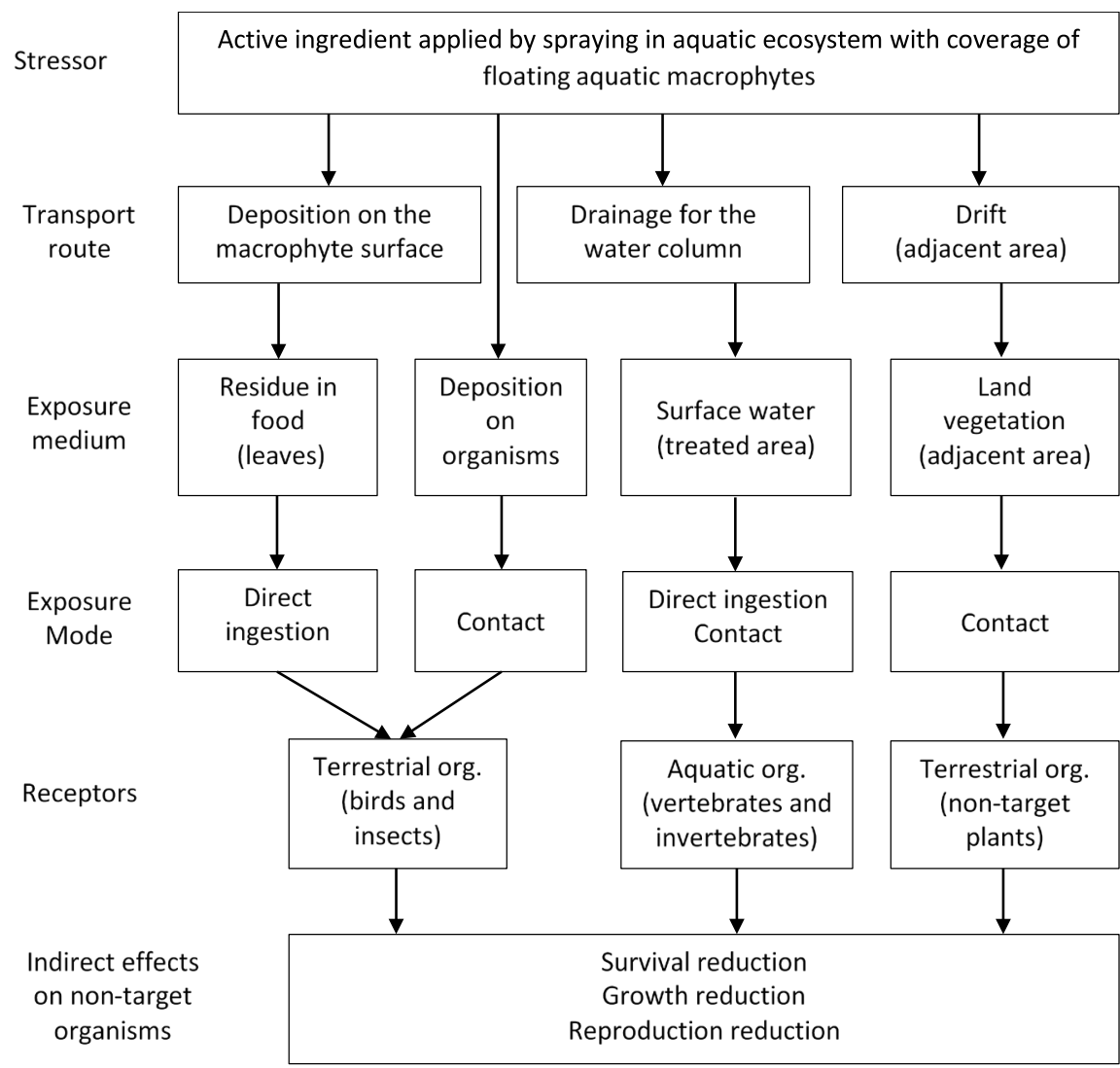

Figure 1. Diagram of the conceptual model describing the environmental risk related to the glyphosate use to control floating aquatic macrophytes. was equal to $15.6 \pm 1.5 \mathrm{mg} . \mathrm{L}^{-1}$ (mean \pm std. dev.), ranging from 13.8 to $18.2 \mathrm{mg} . \mathrm{L}^{-1}$. For AMPA metabolite, the mean value recorded was 0.322 $\pm 0.130 \mathrm{mg} . \mathrm{L}^{-1}$. During all the experimental period, the highest concentration values for the AMPA metabolite were verified from $5^{\text {th }}$ to $10^{\text {th }}$ day with a maximum value equal to $0.553 \mathrm{mg} \cdot \mathrm{L}^{-1}$. The maximum environmental concentrations obtained in the microcosms were used for the $\mathrm{RQ}$ calculation.

Table III has the results of the ecotoxicological assays for the active ingredient of glyphosate, AMPA metabolite and the commercial formulation Roundup Original ${ }^{\varpi}$.

The acute risk quotient was calculated for the two evaluated species, taking into account the most sensitive species for each product or the most relevant toxic response, when the focus falls on the survival levels about the biochemical responses.
Some effects on diversity of species can be tolerated. At this sense, measures of survival, reproduction and/or growth tend to be more useful than those based on physiological or biochemical responses that are not clearly related to specificities of the population or community. For instance, the decrease of the luminescence observed for A. fischeri. (IBAMA 2012).

The relevance of making ecotoxicological assessments with more than one species is because some bioindicators are less sensitive to certain substances, as occurred to the $A$. fischeri species in the assay with the commercial formulation of glyphosate. It may be due to the lower toxic effect of the inert substance present in the commercial formulation of glyphosate for this species.

A. fischeri species, saltwater bacteria, is less representative than $D$. similis in evaluating 
freshwater aquatic environments. However, this study becomes relevant because it represents another trophic level that may be affected in a similar way.

The commercial formulation of glyphosate had a higher toxicity when compared to its active ingredient. Therefore, this first had its RQ calculated in order to support the understanding of the dynamics and potential risks related to its use for the control of aquatic floating macrophytes.

Table IV has the results of chronic and acute RQ for the three compounds evaluated. Results obtained for the active ingredient of glyphosate, as recommended by the Environmental Protection Agency of the United States, did not indicate acute or chronic risk for microcrustaceans. However, once A. fischeri species had greater sensitivity some acute risk may exist.

Commercial formulation of glyphosate had acute and chronic RQ higher than the risk assumption ( $R Q>1.0)$. Thus, this result may be an alert due to the difference between the risk presented by the active ingredient and the commercial formulation, which has other substances in its content. AMPA metabolite did not present any chronic or acute environmental risks, possibly because of its low concentration of formation in water.

For the risk characterization for glyphosate, it is important to understand the risk quotient results for both the active ingredient and its commercial formulation in order to establish a use risk assessment. Analyzes of samples collected 24 hours after the application of the commercial formulation of glyphosate in microcosms were crucial and results did not indicate chronic or acute effect for any tested species, even with glyphosate concentrations higher than the $E C_{(1) 50}$ and ECNO values.

All microcosms had their surface completely covered by floating macrophytes at the time of application. This fact may have worked as a filter in retaining the surfactant. Finally, observations of the ecotoxicological effect were performed at community level in the microcosms after the herbicide application and no abnormalities were detected.

Table II. Glyphosate environmental concentration and AMPA measured in the microcosms.

\begin{tabular}{|c|c|c|c|c|}
\hline Parameter & $\begin{array}{c}\text { Mean } \\
\mathbf{m g} \cdot \mathbf{L}^{-\mathbf{1}}\end{array}$ & $\begin{array}{c}\text { Minimum } \\
\mathbf{m g} \cdot \mathbf{L}^{-\mathbf{1}}\end{array}$ & $\begin{array}{c}\text { Maximum } \\
\mathbf{m g} \cdot \mathbf{L}^{-\mathbf{1}}\end{array}$ & $\begin{array}{c}\text { Standard deviation } \\
\mathbf{m g} \cdot \mathbf{L}^{-\mathbf{1}}\end{array}$ \\
\hline Glyphosate & 15.6 & 13.8 & 18.2 & 1.5 \\
\hline AMPA & 0.322 & 0.186 & 0.553 & 0.130 \\
\hline
\end{tabular}

Table III. Ecotoxicological results.

\begin{tabular}{|c|c|c|c|}
\hline Sample & $\begin{array}{c}\text { C. dubia } \\
\text { CENO }\end{array}$ & $\begin{array}{c}\text { D. similis } \\
\text { CE(I) }\end{array}$ & $\begin{array}{c}\text { A. } \text { fischeri } \\
\text { CE( }()_{50}\end{array}$ \\
\hline Glyphosate & $27.5 \mathrm{mg} . \mathrm{L}^{-1}$ & $35.13 \mathrm{mg} . \mathrm{L}^{-1}$ & $11.46 \mathrm{mg} . \mathrm{L}^{-1}$ \\
\hline AMPA & $12.5 \mathrm{mg} . \mathrm{L}^{-1}$ & $52.80 \mathrm{mg} . \mathrm{L}^{-1}$ & $20.25 \mathrm{mg} . \mathrm{L}^{-1}$ \\
\hline Roundup & $3.6 \mathrm{mg} \mathrm{e.a.L}$ & $9.00 \mathrm{mg} \mathrm{e.a.} \mathrm{L}^{-1}$ & $20.16 \mathrm{mg} \mathrm{e.a.} \mathrm{L}^{-1}$ \\
\hline
\end{tabular}


Table IV. Risk quotient results (RQ);

\begin{tabular}{|c|c|c|c|}
\hline Compound & $\begin{array}{c}\text { RQ - chronic } \\
\text { CA / ECNO }\end{array}$ & $\begin{array}{c}\text { RQ - acute }- \text { D.similis } \\
\text { CA / EC(I) }\end{array}$ & $\begin{array}{c}\text { RQ - acute }- \text { A.fischeri } \\
\text { CA / EC(I) }\end{array}$ \\
\hline Glyphosate standard & 0.66 & 0.52 & $\mathbf{1 . 5 9}$ \\
\hline AMPA standard & 0.04 & 0.01 & 0.03 \\
\hline Commercial formulation & $\mathbf{5 . 0 6}$ & $\mathbf{2 . 0 2}$ & 0.90 \\
\hline
\end{tabular}

\section{CONCLUSIONS}

Physicochemical characteristics of glyphosate corroborate its low volatility and high solubility in water with potential to be adsorbed by sediments. Glyphosate presents an acidic characteristic with four dissociation constants, which indicates possible ionic changes in environments with $\mathrm{pH}$ ranging from 2 to 10. This latter condition may reflects the glyphosate susceptibility to $\mathrm{pH}$ and its short half-life in natural environments, about 3.6 days.

The conceptual model diagram has indicated indirect ecological risk related to the application by drift or direct contact with nontarget organisms, not only to aquatic organisms but also to terrestrial organisms.

By the risk quotient, the study indicated that glyphosate does not have risk to microcrustaceans survival or reproduction, but it may cause adverse effects to non-target and more sensitive organisms. Thus, further studies specifically designed to examine the considered effects as well as testing non-target organisms are needed.

The AMPA metabolite had no apparent ecological risk, even with toxic effect, probably due to its formation in low concentrations in the aquatic ecosystem. Moreover, the commercial formulation of glyphosate is a mixture of substances that could makes it more toxic than the active ingredient. It was also observed that the high toxicity can be removed when the commercial formulation is applied correctly in an area completely covered with floating aquatic macrophytes.

The maximum environmental concentrations reached in the aquatic microcosm study by using commercial formulation of glyphosate, applied at 100 L.ha $^{-1}$, for controlling aquatic macrophytes do not demonstrate any risk for aquatic invertebrates. Finally, it must be highlighted that the study considered a condition of unique application of glyphosate in environments with the surface of the water completely covered by the floating aquatic plants.

\section{Acknowledgments}

The authors are grateful for the valuable contributions of the Botanical Garden of the Zoo-Botanic Foundation from Belo Horizonte/MG and Foundation for Research Support of Minas Gerais/Brazil - FAPEMIG.

\section{REFERENCES}

ASSOCIAÇÃO BRASILEIRA DE NORMAS TÉCNICAS. 2012. NBR 15411-2. Ecotoxicologia Aquática - Determinação do efeito inibitório de amostras aquosas sobre a emissão de luz de Vibrio fisheri (ensaio de bactéria luminescente).

ASSOCIAÇÃO BRASILEIRA DE NORMAS TÉCNICAS. 2016a. NBR 12713. Ecotoxicologia Aquática - Toxicidade aguda - Método de ensaio com Daphnia spp (Crustacea. Cladocera).

ASSOCIAÇÃO BRASILEIRA DE NORMAS TÉCNICAS. 2016b. NBR 13373. Ecotoxicologia Aquática - Toxicidade crônica Método de ensaio com Ceriodaphnia spp (Crustacea. Cladocera).

BELTRÃO DS. 2010. Efeitos da aplicação de glifosato na química de solos alagados. Dissertação (Mestrado). 
Universidade Federal de Goiás. Escola de Agronomia e Engenharia de Alimentos. Goiás: 111 p. (Unpublished).

BRASIL. 2002. Decreto Federal $n^{\circ}$ 4071. de 04 de janeiro de 2002. Regulamenta a Lei no 7.802. de 11 de julho de 1989. que dispõe sobre a pesquisa. a experimentação. a produção. a embalagem e rotulagem. o transporte. o armazenamento. a comercialização. a propaganda comercial. a utilização. a importação. a exportação. o destino final dos resíduos e embalagens. o registro. a classificação. o controle. a inspeção e a fiscalização de agrotóxicos. seus componentes e afins e dá outras providências. Brasília: Publicado no D.O.U de 08 de janeiro de 2002.

BROCK TC. 2013. Priorities to Improve the Ecological Risk Assessment and Management for Pesticides in Surface Water. Integr Enviro Assess Manag 9(3): 64-74.

CABRERA L, COSTA FP \& PRIMEL EG. 2008. Estimativa de risco de contaminação das águas por pesticidas na região sul do Estado do RS. Química Nova 31(8): 1982-1986.

CARVALHO LB. 2013. Herbicidas. Lages. Santa Catarina: distribuído pelo autor, $62 \mathrm{p}$.

COPAM - CONSELHO ESTADUAL DE POLÍTICAS PÚBLICAS. 2008. Deliberação Normativa Conjunta COPAM/CERH-MG n 01. de 05 de maio de 2008. Dispões sobre a classificação dos corpos de água e diretrizes ambientais para o seu enquadramento. bem como estabelece as condições e padrões de lançamento de efluentes. e dá outras providências.

CONAMA - CONSELHO NACIONAL DE MEIO AMBIENTE. 2005. Resolução $n^{\circ}$ 357. Dispõe sobre a classificação dos corpos de água e diretrizes ambientais para o seu enquadramento. bem como estabelece as condições e padrões de lançamento de efluentes. e dá outras providências. Brasília. DF. n. 53. De 18 março de 2005.

CONAMA - CONSELHO NACIONAL DE MEIO AMBIENTE. 2011. Resolução CONAMA no 430. de 13 de maio de 2011. Dispõe sobre as condições e padrões de lançamento de efluentes. complementa e altera a Resolução no 357/2005. Conselho Nacional do Meio Ambiente: CONAMA. Brasília. DF. Maio de 2011.

CONAMA - CONSELHO NACIONAL DO MEIO AMBIENTE. Resolução no 467 de 16 de julho de 2015. Dispõe sobre critérios para a autorização de uso de produtos ou de agentes de processos físicos. químicos ou biológicos para o controle de organismos ou contaminantes em corpos hídricos superficiais.

HAYASHI TI, IMAIZUMI Y, YOKOMIZO H, ATARAZAKO N \& SUZUKI N. 2016. Ecological risk assessment of herbicides in japan: integrating spatiotemporal variation in exposure and effects using a multimedia model and algal density dynamics models. Environ Toxicol Chem 35(1): 233-240.

IBAMA - INSTITUTO BRASILEIRO DO MEIO AMBIENTE E DOS RECURSOS NATURAIS RENOVÁVEIS. 1996. Portaria Normativa Ibama no 84. de 15 de outubro de 1996. Estabelece procedimentos a serem adotados junto ao Instituto Brasileiro do Meio Ambiente e dos Recursos Naturais Renováveis - IBAMA. para efeito de registro e avaliação do potencial de periculosidade ambiental - (ppa) de agrotóxicos. seus componentes e afins. Brasília: Publicado no D.O.U. de 18 de outubro de 1996.

IBAMA - INSTITUTO BRASILEIRO DO MEIO AMBIENTE E DOS RECURSOS NATURAIS RENOVÁVEIS. 2012. Avaliação de risco ambiental de agrotóxicos no Ibama. Santos. Marlos Moreira dos, 23 p.

INAO K, WATANABE H, KARPOUZAS DG \& CAPRI E. 2008. RevieW - Simulation Models of Pesticide fate and Transport in paddy Environment for Ecological Risk. Assessment and Management. JARQ 42(1): 13-21.

MINISTÉRIO DA SAÚDE. 2011. Portaria no 2914/MS de 2011. Dispõe sobre os procedimentos de controle e de vigilância da qualidade da água para consumo humano e seu padrão de potabilidade. Ministério da Saúde. Brasillia. DF. Dezembro de 2011.

PANIZZI S, SUCIU NA \& TREVISAN M. 2016. Combined ecotoxicological risk assessment in the frame of European authorization of pesticides. Sci Total Environ 580: 136-146.

PETERSON RKD \& HULTINGAG. 2004. A comparative ecological risk assessment for herbicides used on spring wheat: the effect of glyphosate when used within a glyphosatetolerant wheat system. Weed Science 52(5): 834-844.

PRATA F. 2002. Comportamento do glifosato no solo e deslocamento miscivel de atrazina. Tese (doutorado). Escola Superior de Agricultura Luiz de Queiroz. Piracicaba, 149 p.

QU CS, CHEN W, BI J, HUANG L \& LI FY. 2011. Ecological risk assessment of pesticide residues in Taihu Lake wetland. China. Ecological Modelling: 222: 287-292.

SANTOS S C. 2012. Desenvolvimento de uma metodologia eletroanalítica para a determinação de pesticida glifosato em amostras ambientais. Dissertação (mestrado) Universidade Estadual do Centro-Oeste. Programa de Pós-graduação em Química. Guarapuava, 74 p. (Unpublished).

SOLOMON KR, GIESY JP, LAPOINT TW, GIDDINGS JM, RICHARDS RP. 2013. Ecological risk assessment of atrazine in north 
american surface waters. Enrivon Toxicol Chem 32(1): $10-11$.

USEPA - U. S. ENVIRONMENTAL PROTECTION AGENCY. 2004. Overview of the Ecological Risk Assessment Process in the Office of Pesticide Programs. U. S. Environmental Protection Agency: Endangered and Threatened Species Effects Determinations. Office of prevention. pesticides and toxic substances. Office of pesticide programs. Washington. D.C., 92 p.

WEST I \& DAVE G. 1994a. EPA PROBIT Version 1.5. Wyoming: University of Wyoming.

WEST I \& DAVE G. 1994b. TOXTAT Version 3.3. Wyoming: University of Wyoming.

\section{How to cite}

MARIA MA, CASTRO SR, LANGE LC SIÚVES CLF \& SOARES AC. 2020. Ecological risk assessment of glyphosate in surface water when it is used to control floating aquatic macrophytes. An Acad Bras Cienc 92: e20180445. DOI 10.1590/0001-3765202020180445.

Manuscript received on May 5, 2018; accepted

for publication on September 30, 2018

MARINA ANDRADA MARIA ${ }^{1,2}$

https://orcid.org/0000-0002-9373-1819

\section{SAMUEL R. CASTRO 3}

https://orcid.org/0000-0003-4053-7040

\section{LISÉTE C. LANGE ${ }^{2}$}

https://orcid.org/0000-0002-5768-8729

\section{CLÁUDIA L.F. SIÚVES ${ }^{1}$}

https://orcid.org/0000-0001-5074-062X

\section{AYLTON CARLOS SOARES ${ }^{1}$}

https://orcid.org/0000-0002-3477-3277

${ }^{1}$ Institute SENAI of Technology in Environment, Innovation and Technology Center, SENAI-FIEMG, 2000 José Cândido da Silveira Avenue, Horto, 31035-536 Belo Horizonte, MG, Brazil

${ }^{2}$ Federal University of Minas Gerais, Department of Sanitary and Environmental Engineering, 6627 Presidente Antônio Carlos Avenue, Pampulha, 31270-901 Belo Horizonte. MG, Brazil ${ }^{3}$ Federal University of Juiz de Fora, Department of Sanitary and Environmental Engineering, José Lourenço Kelmer Street, São Pedro, 36036-900 Juiz de Fora, MG, Brazil

Correspondence to: Maria Andrada Maria

E-mail:mamaria@fiemg.com.br

\section{Author contributions}

This work was part of the doctoral project of researcher Marina Andrada Maria, headed by professor Liséte Celina Lange. Ayton Carlos Soares and Cláudia Lauria Fróes Siúves supported in conducting and carrying out the experiments and Professor Samuel Rodrigues Castro contributed to the data analysis and writing of this document.

\section{(cc) BY}

